\title{
Pengembangan Inovasi Sosial Digital: Studi Kasus Pasarsambilegi.id
}

\author{
Matahari Farransahat ${ }^{1}$, Acniah Damayanti ${ }^{2}$, Hempri Suyatna ${ }^{3}$, Puthut Indroyono ${ }^{4}$, \\ Rindu Sanubari Mashita Firdaus ${ }^{5}$
}

\begin{abstract}
Abstrak
Belum ditemukannya vaksin COVID-19 membuat perkembangan inovasi sosial berbasis digital berkembang pesat, dan terbukti efektif dalam menanggulangi penyebaran COVID-19. Tulisan ini bertujuan untuk mengetahui bagaimana proses pengembangan inovasi sosial berbasis digital merespon COVID-19 dilakukan. Ini dilakukan dengan mengambil kasus penelitian pada web-apps pasarsambilegi.id, yang merupakan sistem belanja daring pada pasar tradisional di DI. Yogyakarta. Metode penelitian kualitatif dilakukan dengan pengambilan data primer melalui observasi dan wawancara mendalam, sedangkan data sekunder melalui studi literatur. Hasilnya proses pengembangan inovasi sosial pasarsambilegi.id memiliki komponen penyusun yang sama dengan program kewirausahaan sosial. Diketahui kebaruan nilai sosial telah tercapai, namun belum diikuti dengan perubahan sistemik seperti yang diharapkan, karena masih membutuhkan waktu promosi lebih lama untuk meningkatkan jumlah pengguna.
\end{abstract}

Kata Kunci: inovasi sosial; belanja daring; COVID-19; pasar tradisional; kewirausahaan sosial

\begin{abstract}
The absence of a COVID-19 vaccine has made the development of digital-based social innovation grow rapidly, and has proven effectively in tackling the spread of COVID-19. This paper aims to examine how the process of developing digital-based social innovation in response to COVID-19 is performed. It is done by research case on the pasarsambilegi. id web-apps, which is an online shopping system in traditional markets in the province of DI. Yogyakarta. The qualitative research method is carried out by collecting primary data through observations and in-depth interviews, while secondary data through literature studies. The results of the process of developing social innovation in pasarsambilegi.id has the identical essential components as the social entrepreneurship program. It is identified that the novelty of social values has been achieved, but has not been followed by systemic changes as expected, owing to it takes longer time for promoting in order to increase the number of users.
\end{abstract}

Keywords: social innovation; online shopping; COVID-19; traditional markets; social entrepreneurship

\section{Pendahuluan}

Sampai saat ini jumlah penularan virus COVID-19 masih terus merebak. Gugus Tugas COVID-19 pada tanggal 31 Juli 2020 merilis informasi bahwa terdapat sebanyak 108.376 orang yang terkonfirmasi positif dan sebanyak 5.131 orang telah meninggal dunia diakibatkan oleh virus ini di wilayah Indonesia (Bencana, 2020). Belum ditemukannya vaksin pada virus ini menjadikan tingkat kesembuhan pasien terpapar sangat rendah. Masih dari sumber data yang sama, tercatat terdapat 65.907orang yang telah berhasil sembuh. Berbagai langkah kebijakan telah diambil pemerintah sebagai upaya mengurangi risiko penularan virus tersebut. Diantaranya adalah dengan menetapkan pemberlakuan Pembatasan Sosial Berskala Besar (PSBB). Pada pelaksanaannya beberapa kegiatan mendapat perkecualian. Salah satunya adalah kegiatan berbelanja

\footnotetext{
${ }^{1}$ Departemen Pembangunan Sosial dan Kesejahteraan, Universitas Gadjah Mada (email korespondensi: matahari.farransahat@ugm.ac.id)

${ }^{2}$ Departemen Komunikasi, Universitas Gadjah Mada (email: acniah.damayanti@ugm.ac.id)

${ }^{3}$ Departemen Pembangunan Sosial dan Kesejahteraan, Universitas Gadjah Mada (email: hempriugm@ gmail.com)

${ }^{4}$ Pusat Studi Ekonomi Kerakyatan Universitas Gadjah Mada (email: puthut@ugm.ac.id)

${ }^{5}$ Pusat Studi Ekonomi Kerakyatan Universitas Gadjah Mada (email: rindufirdaus09@gmail.com)
} 
di pasar rakyat (pasar tradisional), demi menjaga kelangsungan ekonomi dan pemenuhan kebutuhan pokok pangan.

Sebagai upaya pencegahan penularan COVID-19 di pasar tradisional, pemerintah pada akhir bulan Mei 2020 telah mengeluarkan Surat Edaran Menteri Perdagangan No. 12/2020 tentang "Pemulihan Aktivitas Perdagangan pada Masa Pandemi COVID-19 dan New Normal". Berapa hal diantaranya adalah kewajiban dalam menerapkan protokol kesehatan yang ketat seperti kewajiban memakai masker, melakukan jaga jarak, pengecekan suhu tubuh sebelum masuk pasar, penyediaan sarana cuci tangan dengan sabun, sampai dengan penyemprotan disinfektan secara berkala dua hari sekali. Sayangnya hal tersebut tidak terbukti dapat menjamin keamanan dari penularan virus COVID-19. Berdasarkan pernyataan dr. Reisa Broto Asmoro, selaku Anggota Tim Komunikasi Publik Gugus Tugas Percepatan Penanganan COVID-19, diketahui bahwa lebih dari 400 pedagang pasar di 93 pasar tradisional telah terinfeksi COVID-19 berdasarkan tes cepat yang telah dilakukan. Dia juga meyampaikan bahwa pasar tradisional menjadi lokasi yang rentan dalam penularan COVID-19. Sebab, banyak sekali orang yang melakukan aktivitas berbelanja dari berbagai tempat dengan kondisi berdesakan. Selain faktor kebersihan dan standar sanitasi dan higenitas yang kurang terjaga (Kompas, 2020).

Kondisi pada pasar tradisional menjadikan pemerintah dan berbagai pemangku kepentingan berada pada pilihan dilematis. Di satu sisi pembatasan pada kegiatan perdagangan akan memberatkan ekonomi masyarakat dan pemenuhan kebutuhannya, di sisi lain pengendalian penularan virus masih sulit dilakukan. Salah satu harapan besar ada pada pemanfaatan teknologi digital, yang diketahui telah mampu menjadi best practices penurunan risiko penularan COVID-19 di berbagai negara. Seperti di Negara China, keberhasilan pengurangan risiko penularan COVID-19 di Propinsi Wuhan sebagai pusat episetrum, telah sukses dilakukan dengan menggunakan inovasi sosial berbasis teknologi digital. Mereka menerapkan pelaporan status kesehatan yang disematkan pada setiap orang dengan menggunakan bantuan smartphone. Kode yang berbeda pada tiap orang akan menandakan boleh tidaknya seseorang pergi meninggalkan rumah, dan untuk tujuan apa dia boleh pergi (Insider, 2020). Terkait dengan pemenuhan kebutuhan bahan pokoknya, penggunaan platform online-to-offline (020) memudahkan setiap orang yang menjalani karantina di China untuk bisa melakukan konsultasi medis dan kegiatan berbelanja untuk pemenuhan kebutuhan hariannya. Platform ini secara otomatis terhubung dengan warung mitra terdekat, sehingga kebutuhan yang diinginkan dapat dipenuhi dengan cepat (Accenture, 2020).

Berbagai cara telah dilakukan oleh banyak pihak di seluruh dunia untuk melakukan penanggulangan penularan COVID-19 melalui inovasi sosial berbasis digital. Penelitian yang dilakukan oleh Ting (2020) pada berbagai negara, memperlihatkan ada enam fungsi pada penggunaan aplikasi teknologi digital dalam menanggulagi wabah virus COVID-19. Fungsi tersebut antara lain untuk pengawasan virus; pemindaian seseorang atas virus; pelacakan kontak; karantina dan isolasi mandiri; serta pengelolaan diagnosa klinis. Pada penerapannya, terdapat banyak cara kreatif yang dilakukan, yaitu dengan mengintegrasikannya dalam berbagai hal, mulai dari smartphone, global positioning system, data dashboard, learning machine, web-based platform sampai dengan penciptaan kecerdasan buatan dan berbagai hal berbasis teknologi digital lainnya. Hasil dari penelitian tersebut menyatakan bahwa integrasi teknologi digital dalam merespon pandemi COVID-19, merupakan penerapan dari negara-negara yang berhasil meratakan kurva prevalensi COVID-19 dan mengontrol jumlah kematian yang rendah.

Dengan demikian, dirasa penting bagi seluruh pemangku kepentingan yang menangani penanggulangan penyebaran COVID-19 untuk bisa mengembangkan inovasi sosial berbasis digital. Diketahui, tidak mudah untuk mengembangkan inovasi sosial yang dapat melibatkan masyarakat sampai dengan mencapai outcome yang diharapkan. Terlebih, sampai menghasilkan perubahan yang sistemik (social impact). Murray dkk. (2010) menyatakan bahwa terdapat beberapa tahapan pada proses pengembangan inovasi sosial untuk sampai bisa menghasilkan perubahan yang sistemik. Meskipun bisa jadi tahapan - tahapan tersebut tidak dilalui secara berurutan bahkan saling bersilangan. Hal tersebut sangat tergantung dengan perbedaan budaya dan tingkat kapasitas 
Matahari Farransahat, Acniah Damayanti, Hempri Suyatna, Puthut Indroyono, Rindu Sanubari Mashita Firdaus Pengembangan Inovasi Sosial Digital: Studi Kasus Pasarsambilegi.id

masyarakat. Oleh karena sulit dan uniknya proses penciptaan sebuah inovasi sosial, maka kajian mengenai hal tersebut dilakukan, dengan mengambil kasus pada sistem belanja daring pasarsambilegi.id, yang merupakan platform web application (web-apps) guna merespon penyebaran COVID-19. Tidak hanya inovasi sosial yang berbasis digital, web-apps yang dikembangkan di pasar tradisional ini juga lekat dengan kegiatan kewirausahaan sosial pada model bisnisnya. Selain mengetahui proses pengembangan inovasi sosial sebuah webapps belanja daring, penelitian ini juga akan memberikan manfaat mengenai hal - hal yang harus diperhatikan dalam mereplikasikannya.

\section{Kerangka Teori}

Menurut Phillis dkk. (2008), inovasi sosial didefinisikan sebagai solusi baru untuk mengatasi masalah sosial dengan lebih efektif, efisien, berkelanjutan, atau hanya sebuah solusi yang telah eksis dengan penambahan penciptaan nilai. Hal tersebut khususnya menyasar kepada masyarakat secara keseluruhan daripada individu-individu atau pribadi-pribadi. Pada definisi lain, istilah inovasi sosial lekat dengan penyertaan peran dari berbagai pihak dalam menyelesaikan suatu masalah sosial. Murray dkk. (Murray et al., 2010) menyatakan bahwa ruang lingkup inovasi sosial sangatlah luas dan tidak memiliki batasan yang tetap serta dapat terjadi di semua sektor. Baik pada sektor publik, sektor nirlaba (masyarakat sipil), dan juga sektor swasta. Diketahui banyak dari kreasi penciptaan inovasi sosial terjadi pada irisan antar sektor (Murray dkk., 2010). Secara umum istilah inovasi sosial dapat digunakan untuk mendeskripsikan beberapa hal, diantaranya (Caulier-Grice dkk., 2012): transformasi sosial; bisnis model pada manajemen organisasi; aktifitas kewirausahaan sosial; pengembangan produk, jasa dan program baru; serta sebuah model mengenai tata kelola (governance), pemberdayaan (empowerment) dan peningkatan kapasitas (capacity building).

Tracey dan Stott (2017) membagi bentuk inovasi sosial ke dalam tiga tipologi, yaitu social entrepreneurship, social intrapreneurship, dan social extrapreneurship. Karakteristik yang serupa dari ketiga tipologi tersebut adalah masing-masing tujuannya untuk mengatasi permasalahan sosial. Aspek yang kemudian membedakan ketiganya menurut Tracey dan Stott yaitu proses penciptaan inovasi dan pelibatan aktor di dalam proses tersebut. Social entrepreneurship merupakan sebuah upaya penciptaan aktivitas bisnis baru yang mampu menjawab berbagai kebutuhan sosial di komunitas lokal dan global, yang tidak dapat ditanggapi oleh skema konvensional (Tanimoto, 2012). Social intrapreneurship merupakan pencipataan perubahan dari dalam organsisasi dengan mengoptimalkan kapasitas dan sumber daya yang tersedia (Tracey \& Stott, 2017). Tipologi terakhir, social extrapreneurship menurut Tracey dan Stott merupakan proses kolaborasi antar organisasi yang mengakomodasi kombinasi ide, ruang, dan sumber daya untuk menciptakan perubahan sosial melalui upaya kolektif.

Inovasi merupakan salah satu elemen kunci yang diperlukan dalam proses penciptaan kewirausahaan sosial (Okpara \& Halkias, 2011) atau upaya-upaya yang dilakukan untuk menciptakan kegiatan bernilai ekonomi dengan tujuan mengatasi permasalahan sosial. Menurut Halkias dan Okpara, faktor-faktor penunjang yang harus hadir dalam kewirausahaan sosial adalah inovasi dan kreativitas, kepemimpinan (leadership), peluang (opportunity), kemampuan untuk mendatangkan keuntungan (profitability), penciptaan nilai (value creation), dan manfaat sosial (social benefit). Dalam logical framework sebuah program, keempat faktor pertama tersebut tergolong sebagai tahapan input, aktifitas dan keluaran (output) yang saling mempengaruhi. Sedangkan, faktor profitability dan value creation adalah outcome pada proses pengupayaan perubahan, serta social benefit sebagai dampak yang diharapkan.

Pada penciptaannya, inovasi sosial membutuhkan proses dari berbagai tahapan, agar solusi kebaruannya dapat diterima dan digunakan oleh masyarakat luas. Murray dkk. (2010) membagi proses ini ke dalam enam tahapan sebagai berikut:

a. Prompts, inspirations and diagnoses, yaitu proses menemukan akar masalah sosial dan membuat bingkai rumusan masalah dengan tepat. Konseptualiasi masalah merupakan proses fundamental yang selanjutnya berpengaruh pada pengembangan inovasi solusi (Curtis, 2010).

b. Proposals and ideas, yaitu proses mencari solusi atau ide pemecahan masalah dengan memungkinkan adanya partisipasi dan kolaborasi dari berbagi pihak. 
c. Prototyping and pilots, yaitu purwarupa dalam tahapan uji coba ide inovasi untuk melihat apakah layak untuk diterapkan dan mampu mengatasi persoalan.

d. Sustaining, yaitu keberlanjutan inovasi setelah melalui tahapan uji coba. Inovasi membutuhkan elemen-elemen berikut untuk dapat berlanjut; model bisnis, model kontrol dan pengelolaan, pendanaan, jejaring dan komunikasi, pengelolaan sumber daya manusia, dan perencanaan pengembangan.

e. Scaling and diffusion, yaitu proses promosi atau 'pemasaran' ide inovasi sosial kepada masyarakat melalui berbagai platform dan jejaring kolaborasi.

f. Systemic change, yaitu terciptanya perubahan sosial yang sistemik yang didukung oleh beberapa faktor seperti, kerjasama lintas sektor, pelibatan pakar, proses pendampingan dan pelatihan untuk membentuk keterampilan dan sikap, pembuatan kebijakan atau peraturan yang mendukung proses inovasi sosial, serta permberdayaan penerima manfaat inovasi sosial.

Seperti halnya Murray dkk., Dhewanto dkk., (2013) juga memetakan proses penciptaan inovasi sosial dengan memberikan penekanan pada proses kolaborasi baik pada perencanaan maupun pada implementasi inovasi sosial. Sehubungan dengan itu, tahapan pertama dari proses inovasi sosial adalah menemukan masalah sosial, dengan mengekplorasi masalah sosial melalui identifikasi kondisi yang tidak ideal (gap). Kedua, menghasilkan gagasan bersama, dengan bekerjasama dengan para pemangku kepentingan untuk mencari kesesuaian dan persamaan pandangan terhadap suatu masalah sosial, hingga mendapatkan solusi yang disepakati bersama. Ketiga, mengukur dan menyesuaikan kapasitas, dengan cara mengukur kemampuan diri dengan melakukan studi kelayakan terhadap program yang akan dijalankan. Keempat, melakukan kerjasama dengan mitra, dilakukan secara kolaboratif dengan berbagai relasi dari berbagai bidang. Kelima, menghasilkan inovasi sosial, yang mampu memecahkan masalah sosial dan berdampak baik terhadap masyarakat.

Mulgan (2006) menambahkan aspek learning and evolving dalam proses inovasi sosial. Inovasi merupakan suatu proses yang dinamis dan senantiasa berubah sehingga di dalam ekosistemnya yang kompleks, saling terhubung, dan terkadang saling berkontradiksi, terdapat proses pembelajaran, adaptasi, dan evolusi ide melalui proses kolaborasi kreatif dan proaktif (Manzini, 2014; Mulgan, 2006). Sifat inovasi yang baru, kompleks, dan senantiasa berubah memunculkan berbagai risiko kegagalan jika tidak dikelola dengan baik. Beberapa faktor yang dapat memengaruhi kegagalan inovasi misalnya tingkat kegunaan yang rendah, mekanisme promosi yang kurang, serta kurangnya dukungan pemangku kebijakan (Mulgan, 2006). Mulgan menambahkan bahwa proses inovasi akan lebih mudah jika risiko mampu diminimalisasi, terdapat bukti kegagalan di masa lalu yang hendak diperbaiki dengan inovasi, penerima manfaat mempunyai alternatif atau pilihanpilihan dalam pemanfaatan inovasi, dan terdapat pengelolaan ekspektasi penerima manfaat.

Dewasa ini, perkembangan teknologi komunikasi dan informasi turut membantu memfasilitasi akselerasi proses inovasi sosial (Cui dkk., 2017). Platform internet dan perangkat teknologi digital memungkinkan inovasi kolaboratif di mana seorang inovator, pengguna, dan komunitas bekerjasama menggunakan teknologi digital untukmenciptakan pengetahuan dan solusi dari berbagai kebutuhan sosial (Bria dkk., 2014) dengan pendekatan bottom-up (Cangiano dkk., 2017) secara lebih efisien, efektif, dan berkelanjutan (Anania \& Passani, 2014). Penelitian Bria dkk. (2014) menyatakan bahwa hal utama yang mempengaruhi penciptaan dan penyebaran inovasi sosial berbasis digital adalah peran aktor non institusional dan masyarakat umum. Tantangannya adalah tentang bagaimana cara mengeksploitasi kekuatan kolaboratif dari berbagai jaringan. Baik jaringan komunitas, jaringan pengetahuan dan hal apapun yang terhubung, untuk dapat dimanfaatkan bersamasama, sehingga dapat meningkatkan kemampuan kolektif komunitas guna mengatasi tantangan sosial yang besar.

Kemampuan kolektif komunitas ini menjadi salah satu modal atau kekuatan dalam proses inovasi digital (Yue dkk., 2015). Proses inovasi sosial digital sendiri merupakan proses pemberdayaan yang melalui tahapan power shifting dan power reforming, yaitu proses alih kuasa pengetahuan yang bersumber dari individu-individu di dalam komunitas dan juga pengetahuan eksternal, untuk diinternalisasi dan 
Matahari Farransahat, Acniah Damayanti, Hempri Suyatna, Puthut Indroyono, Rindu Sanubari Mashita Firdaus Pengembangan Inovasi Sosial Digital: Studi Kasus Pasarsambilegi.id

dikelola secara kolektif oleh komunitas untuk dapat berdaya secara komunal. Langkah-langkah dalam tahapan power shifting meliputi pemetaan pengetahuan dan penggunaan teknologi oleh masyarakat (recognition) serta penyiapan struktur minimal inovasi sosial (preparation) berupa pengetahuan dan sumber daya kolektif yang memungkinkan praktik-praktik sosial baru dapat berjalan. Selanjutnya, pada tahapan power reforming terdapat pemanfaatan sumber daya dan pengetahuan teknologi dengan pelibatan kolaborasi eksternal (recombination) untuk mewujudkan komunitas yang berdaya, mandiri dan minim intervensi pihak eksternal (governance), misalnya pembuat kebijakan Meskipun menurut West (2013), perubahan kebijakan untuk menciptakan iklim kondusif bagi berkembangnya inovasi merupakan faktor yang menentukan keberhasilan inovasi digital, selain keberadaan teknologi baru dan restrukturisasi kelembagaan yang menjamin kelancaran aliran proses difusi inovasi.

\section{Metode Penelitian}

Penelitian ini merupakan penelitian kualitatif dengan metode studi kasus. Studi kasus digunakan untuk mengetahui proses inovasi sosial pada platform pasarsambilegi.id. Data primer dikumpulkan dengan menggunakan teknik wawancara mendalam dan observasi. Wawancara dilakukan pada 13 narasumber kunci yang berperan dalam proses perencanaan hingga implementasi pasarsambilegi.id, yaitu pengurus paguyuban pedagang Pasar Sambilegi, Dinas Perindustrian dan Perdagangan Kabupaten Sleman, serta tim pengembang platform pasarsambilegi.id dari Universitas Gadjah Mada. Observasi dilakukan dari bulan Juni hingga Juli 2020 dengan mengamati proses pemanfaatan website pasarsambilegi.id oleh pedagang Pasar Sambilegi. Data sekunder dalam penelitian ini didapatkan melalui studi literatur terkait inovasi sosial, dokumen proses kelembagaan Pasar Sambilegi yang diinisiasi Sekolah Pasar Rakyat, dokumen kebijakan pemerintah terkait pemulihan ekonomi saat pandemi, serta berita di media terkait kondisi pasar rakyat di saat pandemi serta berita mengenai pasarsambilegi. id. Data dianalisis secara deskriptif dengan menggunakan tahapan proses inovasi Murray dkk (2010) untuk menjabarkan masingmasing tahapan proses inovasi sosial pada pasarsambilegi.id. Analisis juga akan melihat komponen pembentuk kewirausahaan sosial berdasarkan konsep Okpara dan Halkias (2011) pada praktik pasarsambilegi.id.

\section{Hasil}

Proses pengembangan inovasi sosial webapps pasarsambilegi.id akan dijelaskan dalam lima tahapan yang memuat esensi tahapan inovasi sosial yang dituliskan oleh Murray dkk. (2010). Tiap tahapan memuat penjelasan mengenai komponen pembentuk kewirausahaan sosial yang disusun oleh Okpara dan kawankawan (2011).

\section{Merespon Masalah COVID-19}

Proses penciptaan dan pengembangan webapps pasarsambilegi.id diawali dengan kegiatan mengindentifikasi dan merespon kesulitan berbelanja di pasar tradisional sebagai masalah sosial oleh para aktor. Diketahui, pada kuartal kedua tahun 2020 kegiatan berbelanja di Pasar Tradisional Sambilegi mengalami penurunan, seiring dengan penularan infeksi virus COVID-19 yang tidak kunjung mereda. Keadaan pasar sepi dari pengunjung dan para pedagang senantiasa mengeluhkan pendapatannya. Beberapa pedagang memilih menutup los dan kiosnya dan hanya membuka pada hari-hari tertentu. Mereka memilih menutup sementara dagangannya, tidak saja karena sepinya pengunjung, melainkan juga khawatir tertular COVID-19. Terlebih, ada diantara mereka yang dilaporkan terinfeksi positif, dan diwajibkan untuk melakukan karantina di rumah sakit, yang sebelumnya diketahui bebas beraktifitas di lingkungan pasar. Meskipun hasil positif tersebut didapatkan dari tes cepat (rapid test), namun kesimpangsiuran informasi pada masyarakat umum mengenai status positifCOVID-19 menyebabkan keresahan yang berarti.

Aktor utama pelaksana model bisnis sistem belanja daring pasarsambilegi.id adalah Paguyuban Pasar Sambilegi. Kelompok yang mengakomodasi kepentingan 348 pedagang yang beraktivitas di 44 kios dan 304 los pasar pada bangunan seluas $4.602 \mathrm{~m}^{2}$. Mereka adalah pedagang pasar yang mendapatkan pendampingan dari Dinas Perindustrian dan Perdagangan (Disperindag) dan terpilih secara mufakat untuk menjalankan program dan kegiatan kelompok paguyuban. Sejak awal pandemi terjadi, mereka terus aktif mencari solusi untuk memperbaiki kondisi pasar. Maka 
tidak sulit bagi Disperindag Sleman, yang bertindak selaku Unit Pelaksana Teknis (UPT) pelayanan pasar kabupaten, ketika menyarankan kepada pengurus untuk melakukan kegiatan berbelanja secara daring. Terlebih, paguyuban Pasar Sambilegi terkenal solid, kooperatif dan terbuka terhadap hal baru. Mereka telah terbiasa melalukan berbagai kerja kolektif antar pedagang, jauh sebelum krisis pandemi melanda. Diantaranya adalah pengelolaan pelayanan listrik, pembangunan dan pemeliharaan mushola, kegiatan koperasi simpan pinjam AlMawadah, dan berbagai fasilitas publik lainnya. Sementara, sifat paguyuban yang terbuka terlihat dengan banyaknya mitra yang dimiliki. Baik dari beberapa perguruan tinggi, maupun organisasi pemerintah lainnya. Kerjasama yang dilakukan dengan perguruan tinggi diantaranya adalah program Sekolah Pasar Rakyat dan kegiatan KKN tematik, sedangkan program kerjasama dengan organisasi pemerintah adalah kegiatan studi banding pengelolaan paguyuban pasar. Mitra kegiatan studi banding tersebut mayoritas berasal dari berbagai wilayah kabupaten di luar Jawa.

Aktor kedua ialah Disperindag Kabupaten Sleman. Sebagai organisasi pemerintah, Disperindag langsung melakukan pendampingan khusus mengenai sistem belanja daring, sebelum Surat Edaran dari Menteri Perdagangan mengenai pemulihan aktivitas perdagangan di pasar rakyat, dikeluarkan. Dari 36 pasar rakyat yang diampu pelayanannya oleh Disperindag, terdapat 24 pasar yang didampingi untuk melakukan pelayanan secara daring dengan meggunakan aplikasi pesan whatsapps terhadap pelanggannya. Diketahui, hanya terdapat beberapa pasar yang berhasil mengimplementasikannya, dan Pasar Sambilegi merupakan salah satu yang terbaik dalam menjalankan model bisnis tersebut. Selanjutnya, untuk meningkatkan keberhasilannya, Disperindag menggandeng pihak perguruan tinggi dalam memberikan kegiatan pelatihan promosi berbelanja daring, dengan mengenalkan fitur whatsapp for business kepada para pedagang pasar.

Selain mendampingi dalam penggunaan sistem daring kepada pasar tradisional, Disperindag juga berupaya menjalin kemitraan dengan pihak swasta, yaitu perusahaan aplikasi berbasis digital Grab dan Gojek. Hal ini dimaksudkan agar tercipta sebuah inovasi model bisnis daring yang terintegrasi pada sistem pelayanan jasa kurir dan transportasi tersebut. Namun upayanya kurang efektif, karena tidak ada kebaruan fitur dari kedua perusahaan tersebut. Fitur dari sistem yang telah ada mengharuskan pedagang pasar tergabung terlebih dahulu sebagai mitra. Padahal, sistem tersebut membutuhkan kepiawaian para pedagang pasar dalam menggunakan smartphone.

Aktor ketiga adalah tim kegiatan pengabdian masyarakat yang berasal dari lingkungan akademisi Universitas Gadjah Mada. Penggerak utamanya adalah tenaga pengajar dari Fakultas Ilmu Sosial dan Politik (ISIPOL) yang bekerja sama dengan para staf Pusat Studi Ekonomi Kerakyatan (Pustek) UGM. Kolaborasi ini diawali oleh gagasan Fakultas Isipol dalam membantu penanganan dampak pandemi yang terjadi. Gagasan tersebut telah menghasilkan beberapa kegiatan, diantaranya: pembagian sembako bagi mahasiswa yang terjebak kondisi "lock-down", pelaksanaan enam kali webinar dengan output policy brief bagi para pemangku kepentingan, sebuah penyusunan buku tata kelola penanganan COVID-19 lintas fakultas, dan lima kegiatan pengabdian masyarakat.

Kegiatan pengabdian masyarakat dilakukan agar langsung menyasar kepada kelompok komunitas dan masyarakat umum, dengan bentuk program yang sangat beragam. Salah satunya adalah program pengembangan sistem belanja daring di Pasar Sambilegi. Dalam perjalanannya, kerjasama antara Fakultas Isipol dan Pustek sebagai tim pengabdian mendapatkan dukungan tim kreatif digital dari Creative Hub (C-Hub) Fisipol UGM. C-Hub merupakan unit kerja di Fakultas Isipol yang berperan menginkubasi pengembangan start-up sosial para mahasiswa. Bantuan yang diberikan oleh tim kreatif C-Hub, tidak saja berupa pengembangan sistem daring yang mutakhir, melainkan juga kerelaan melakukan pekerjaan dengan anggaran yang terbatas.

\section{Menghasilkan Gagasan Bersama}

Pada tahapan ini, ketiga aktor berkolaborasi dalam menghasilkan gagasan bersama. Diketahui tidak sulit bagi mereka untuk menginisiasi sebuah gagasan dalam menangani permasalahan berbelanja di pasar tradisional. Hal tersebut karena diantara ketiganya telah saling berjejaring sebelumnya, dan juga memiliki perhatian serta semangat yang sama pada upaya perbaikan 
Matahari Farransahat, Acniah Damayanti, Hempri Suyatna, Puthut Indroyono, Rindu Sanubari Mashita Firdaus Pengembangan Inovasi Sosial Digital: Studi Kasus Pasarsambilegi.id

dampak COVID-19. Bagi mereka, kebutuhan berkolaborasi memiliki arti dalam penguatan sumber daya bersama. Mereka meyakini, pada perjalanan sebuah program, faktor input yang kuat akan menghasilkan peluang keberhasilan yang lebih tinggi dalam mencapai tujuan.

Dari sudut pandang Tim UGM, bekerjasama dengan Paguyuban Pasar Sambilegi yang merupakan pasar tradisional di bawah pelayanan Disperindag menjadi pilihan terbaik untuk dilakukan. Terdapat tiga faktor utama terkait dengan alasan pemilihan tersebut. Pertama adalah alasan modal sosial. Kuatnya modal sosial pengurus Paguyuban Pasar Sambilegi telah diketahui dari riwayat kerja sama antara Pustek UGM dengan paguyuban. Kerja sama yang dilakukan ialah program pendampingan Sekolah Pasar Rakyat yang dilakukan pada tahun 2013, dan telah berhasil mencapai target outcomenya. Keberhasilan Sekolah Pasar Rakyat terlihat dari berjalannya inisiasi usaha kolektif para pedagang pasar melalui Koperasi Al-Mawadah. Koperasi ini dibentuk oleh para pedagang sendiri di akhir program. Para pedagang sadar bahwa mereka harus memperkuat modal sosial mereka melalui kerja nyata yang dapat menjawab kebutuhan para pedagang. Pada saat itu, kebutuhan para pedagang adalah lepas dari ketergantungan rentenir. Banyak pedagang pasar tradisional yang tidak dapat mengakses fasilitas kredit dari bank sehingga tidak ada pilihan selain ke rentenir. Hingga pada akhirnya, para pedagang yang menjadi peserta Sekolah Pasar Rakyat bersepakat untuk membentuk koperasi, yang pemilik serta pengelolanya adalah para pedagang Pasar Sambilegi.

Meskipun program tersebut telah berakhir, namun beberapa kali kegiatan pendampingan temporer masih dilakukan. Sedangkan faktor kedua adalah alasan lokasi Pasar Sambilegi yang sangat strategis, dan hanya berjarak tidak lebih dua kilometer dari Bandara Internasional Adisucipto, Provinsi DI. Yogyakarta. Oleh karena itu, selain memiliki kepadatan penduduk yang tinggi dan berpotensi menjadi "episentrum" penyebaran COVID-19, terdapat banyak masyarakat golongan ekonomi menengah ke atas yang tinggal di wilayah tersebut. Hal ini terkait erat dengan dengan tingkat melek digital dan penggunaan smartphone. Selanjutnya, pada faktor ketiga adalah alasan potensi keberlanjutan program. Status Pasar Sambilegi sebagai pasar kabupaten diyakini akan memudahkan proses exit strategy program, sehingga akan terjaga keberlanjutannya. Berbagai kendala dikhawatirkan muncul di masa mendatang maupun kebutuhan pengembangannya, tidak akan dihadapi sendirian oleh paguyuban. Selain itu, jika model bisnis daring ini nyata manfaatnya, mudah bagi pasar tradisional ayoman Disperindag lainnya untuk mereplikasi model bisnisnya.

Dari beberapa kali diskusi dan pertemuan, semua aktor setuju bahwa kegiatan berbelanja sistem daring merupakan cara efektif dalam membatasi kontak dan kerumunan. Meskipun pada proses perkembangannya, diskusi tidak pernah menghadirkan ketiga aktor pada satu forum secara bersamaan. Ketika tim pengabdian UGM melakukan identifikasi permasalahan berbelanja di Pasar Sambilegi, mereka mengetahui bahwa paguyuban pasar sedang menjalankan kegiatan belanja daring, yang hanya dengan menggunakan aplikasi berkomunikasi whatsapp. Meskipun sangat sederhana, model bisnis tersebut dapat berjalan cukup efektif. Caranya adalah, konsumen mengirimkan pesan whatsapp kepada tim operator paguyuban mengenai berbagai jenis barang yang diinginkan, beserta informasi lengkap alamat rumahnya. Di sisi lain, setelah mendapatkan pesan, tim operator paguyuban akan membelikan berbagai barang tersebut dari para pedagang pasar. Selanjutnya akan dilakukan pengiriman keesokan harinya bersamaan dengan pemberian uang pembayaran (Cash on Delivery). Terkait dengan keuntungan, yang dibutuhkan sebagai pengganti biaya operasional, didapatkan dari sedikit keuntungan pedagang pasar yang terbeli hasil dagangannya. Tidak ada pengenaan ongkos kirim yang dibebankan kepada konsumen, hanya terdapat persyaratan pembelian minimal sebesar lima puluh ribu rupiah untuk meminimalisir beban operasi. Pada model bisnis ini paguyuban memiliki peran yang sangat sentral sebagai penghubung. Sangat berbeda dengan model bisnis daring yang biasa dilakukan oleh market place, yang membutuhkan kepiawaian penggunaan smartphone oleh pelaku usahanya. Maka, sistem ini dirasa cukup adil bagi para pedagang pasar, karena dapat memberikan akses penjualan barang dagangan mereka.

Telah banyak pelanggan mencoba berbelanja menggunakan sistem daring whatsapp. Beberapa 
diantaranya telah melakukan pembelian berulang. Namun, pengurus paguyuban masih merasakan ketidaknyamanan, terutama mengenai kebutuhan waktu untuk membalas banyak pesan. Seperti pertanyaan mengenai ketersediaan barang, informasi harga dan permintaan informasi khusus lainnya. Hal tersebut membutuhkan konfirmasi berkali-kali agar barang yang diinginkan tidak keliru dengan produk setipe lainnya. Kegiatan membalas pesan pada awalnya tidak merepotkan, namun dengan semakin banyaknya pelanggan, menjawab pertanyaan sembari melakukan kegiatan jual beli di pasar, membuat berbelanja sistem daring aplikasi whatsapp kurang efisien. Selain itu, tidak adanya pengenaan ongkos kirim dan juga pengenaan harga yang sama dengan harga di pasar, menjadikan sistem tidak memberikan keuntungan yang signifikan kepada paguyuban. Mereka menyampaikan, melakukan sistem ini lebih pada motif menolong para pedagang pasar agar terus dapat menjual barang dagangannya. Sayangnya, tidak adanya ongkos kirim, menjadikan paguyuban hanya mau menerima pesanan dari wilayah sekitar yang dekat saja.

Akhirnya, setelah melakukan banyak diskusi dan mendengarkan keluhan dari paguyuban pasar terkait dengan berbagai kesulitannya. Tim pengabdian UGM mencoba mengembangkan sistem daring web-apps dengan model bisnis yang sama dengan sistem whatsapp. Alasan penggunaan web-apps adalah kepraktisannya, karena langsung bisa digunakan tanpa perlu mengunduh dan menginstal aplikasinya, baik di smartphone dan komputer, maupun berbagai dawai lainnya. Selain itu, pengembangan akan diarahkan dengan metode single page application, dengan menggabungkan semua informasi pada pada satu laman. Dengan demikian, web akan memiliki kecepatan tinggi dalam merespon penggunanya karena tidak membutuhkan waktu lagi untuk memanggil laman lainnya. Sedangkan kebaruan yang akan ditambahkan dari sistem sebelumnya adalah adanya informasi mengenai berbagai jenis produk yang dijual beserta harganya. Informasi tersebut nantinya akan diperlihatkan bersama foto asli dan deskripsi produknya, sehingga konsumen tidak akan keliru memilih barang dalam melakukan pemesanan.

\section{Menganalisa Kelayakan Purwarupa dan Melakukan Perbaikan}

Setelah perencanaan betuk web-apps disepakati, tahapan selanjutnya adalah penciptaan purwarupa (prototyping). Tahapan ini dilakukan sembari melakukan analisa kelayakan pada semua lini, terutama hubungan antara fitur web dengan operasional model bisnisnya. Hal tersebut dilakukan dengan terus membangun komunikasi intens antara tim pengabdian UGM, khususnya tim pengembang web dengan tim operator paguyuban. Jika dirasa ada yang kurang layak maka akan dilakukan penyesuaian, bahkan perubahan. Beberapa hal yang dirasakan kurang layak, muncul dari kekhawatiran pengurus paguyuban yang tidak memikirkan lebih jauh sebelumnya. Sebagai tim operasional, mereka khawatir apakah sistem ini akan benar dapat berjalan dan akan menghasilkan keuntungan yang dapat digunakan untuk membiayai kegiatan operasi. Pemikiran tersebut berdasar dari luas wilayah jangkauan pengiriman yang akan dicakup, tanpa adanya pengenaan ongkos kirim. Mereka beranggapan, jika solusinya adalah dengan menaikkan harga jual barang yang lebih tinggi dibandingkan dengan harga di pasar, maka hal tersebut berpotensi untuk ditinggalkan konsumennya. Kekhawatiran yang muncul lainnya adalah kesulitan dalam menggunakan aplikasinya. Diketahui bahwa penggerak yang telah berkomitmen untuk menjalankan sistem ini adalah Bapak dan Ibu Harun selaku ketua dan pengurus paguyuban. Namun mereka merasa tidak muda lagi untuk belajar menggunakan fitur aplikasi di smartphone dengan mudah. Sebagai gambaran, mereka telah mampu mengoperasikan fitur dasar di aplikasi whatsapp dengan baik, telah familiar dengan fungsi aplikasi transportasi Gojek, meski belum pernah mengoperasikannya dengan smartphone-nya sendiri.

Atas alasan tersebut perubahan dilakukan oleh tim pengembang web UGM. Perubahan pertama mengenai pengenaan ongkos kirim dilakukan dengan penambahan fitur perhitungan jarak secara otomatis. Pembeli hanya perlu memilih nama desa tujuan pengiriman yang telah tersedia pilihannya pada sistem. Namun ternyata hal tersebut dirasa kurang sesuai. Pembeli dengan jarak yang signifikan berbeda jauhnya dengan lokasi Pasar Sambilegi, harus membayar ongkos kirim yang sama jika tinggal 
Matahari Farransahat, Acniah Damayanti, Hempri Suyatna, Puthut Indroyono, Rindu Sanubari Mashita Firdaus Pengembangan Inovasi Sosial Digital: Studi Kasus Pasarsambilegi.id

dalam satu wilayah desa yang sama. Pengurus paguyuban berharap perhitungan ongkos kirim dapat dilakukan dengan jarak yang lebih tepat, seperti pada aplikasi Gojek dengan menggunakan fitur google map. Hal tersebut telah diupayakan oleh tim pengembang, meski pada akhirnya diganti lagi, karena penggunaan fitur google map pada sebuah aplikasi mensyaratkan biaya yang tidak murah. Selain juga ada faktor kerumitan dalam cara pembayarannya, yang dikhawatirkan nantinya tidak dapat dilakukan sendiri oleh pengurus paguyuban.

Akhirnya berdasarkan kesepakatan bersama, pembeli diharuskan memilih opsi nama padukuhan dari wilayah desa yang terkover, sehingga jarak lokasi menjadi lebih akurat dan ongkos kirim terasa lebih adil bagi konsumen. Tim pengabdian UGM juga memberikan penjelasan kepada pengurus paguyuban, bahwa bisa jadi yang menggunakan sistem belanja daring ini adalah segmen pasar baru, yang tidak begitu sensitif dengan perubahan harga yang lebih mahal, mengingat pada wilayah jangkauan banyak pemukiman golongan ekonomi kelas menengah ke atas.

Kekhawatiran dalam kesulitan penggunaannya, disiasati oleh tim pengembang web UGM dengan melatih tim operasional paguyuban. Konsultasi dengan pengurus paguyuban selalu dilakukan ketika penambahan modul dasar web telah diciptakan, sebelum hal tersebut terintegrasi dengan fitur lainnya. Pelatihan yang dilakukan diantaranya adalah mengenai cara melihat pesan pembelian, meneruskan kepada tim pengantaran, menjawab pesan konsumen, serta menambahkan produk, termasuk mengunggah gambar, memberikan informasi harga dan deskripsi produknya. Sebenarnya kekhawatiran tersebut tidak saja muncul dari pihak pengurus paguyuban, melainkan juga dari tim pengabdian UGM. Personel tim pengembang web dan anggaran yang terbatas ternyata menjadi kendala dan ketidaknyamanan dalam mengembangkan web-apps yang ideal. Terutama pada kebutuhan penggantian dan penambahan fitur-fitur yang telah disepakati sebelumnya.

\section{Mengupayakan Keberlanjutan dengan Bermitra}

Tidak lama setelah purwarupa dirasakan sempurna, web-apps pasarsambilegi.id mulai dikenalkan kepada masyarakat umum. Dengan harapan akan mendapatkan saran dan perbaikan minor dari para pengguna yang mencobanya. Dari sisi tim operasional paguyuban, sudah tidak merasakan ada kendala lagi, baik dalam menjalankan sistem operasi secara keseluruhan maupun dalam teknis penggunaaan aplikasinya. Bahkan, mereka telah dapat mengunggah produk sendiri kedalam situs web melalui smartphone-nya, tanpa mendapatkan bantuan dari tim pengabdian UGM seperti sebelumnya. Beberapa pelanggan yang sebelumnya menggunakan sistem belanja aplikasi whatsapp mulai berpindah menggunakan web-apps pasarsambilegi.id, dan beberapa dari mereka juga telah melakukan pembelian berulang. Pembelian tersebut membuktikan bahwa sistem telah dapat dijalankan, serta dapat menghasilkan sedikit pendapatan, setelah biaya operasional dikeluarkan dari hasil penjualan

Setelah sistem belanja daring pasarsambilegi. id berhasil digunakan, Disperindag cukup aktif dalam membantu promosi penggunaannya kepada masyarakat luas. Selain itu Disperindag juga memberikan masukan perbaikan, diantaranya adalah mengenai kelengkapan produk-produk pasar yang ditawarkan, dan juga kebutuhan perbaikan dalam mengambil gambar produk. Diskusi multi pihak yang diinisiasi oleh Disperindag juga telah beberapa kali dilakukan sebelum web-apps pasarsambilegi.id diresmikan. Disperindag mempunyai harapan agar sistem belanja daring ini dapat semakin sempurna dan dapat diterapkan di berbagai pasar wilayah pelayanan kerja Disperindag lainnya. Cara yang dilakukan adalah dengan mengenalkan tim pengabdian UGM dengan mitra Disperindag seperti perusahaan Gojek dan Grab dan mitra perguruan tinggi lainnya. Tim pengembang web UGM menyambut inisiatif tersebut dengan mencoba mengaplikasikan sistem google map yang dipunyai perusahaan transportasi tersebut untuk kemudahan pengiriman. Namun upaya tersebut tidak sejalan dengan jasa pelayanan yang sedang dikembangkan oleh kedua perusahaan tersebut.

Tidak lama setelah sering dicoba oleh masyarakat umum, web-apps pasarsambilegi.id diresmikan oleh Fakultas ISIPOL dan Disperindag Kabupaten Sleman. Peresmian dilakukan dengan menyelenggarakan seminar daring yang diikuti oleh para akademia, masyarakat umum, media dan berbagai pemangku kepentingan lainnya. Selain peresmian, tujuan dari pelaksanaan webinar ini adalah untuk mempromosikan 
pasarsambilegi.id agar digunakan oleh banyak pihak. Kegiatan lain yang dilakukan untuk mempromosikan pasarsambilegi.id adalah dengan membagikan selebaran di daerah perumahan, dan juga melalui whatsapp group pada seseorangyang tinggal di wilayah pelayanan. Hal lain yang dilakukan oleh tim pengabdian UGM untuk menggiatkan dan mendukung promosi adalah dengan menambah mitra kerjasama. Khususnya kepada pihak swasta yang menjalankan program CSR yang berada di wilayah Pasar Sambilegi. Hal ini dilakukan agar dapat menyiasati terbatasnya anggaran pada kegiatan ini. Sayangnya gagasan ini belum memperlihatkan hasil karena membutuhkan waktu yang lebih lama dalam mewujudkannya.

\section{Menghasilkan Kebaruan Nilai Sosial}

Dalamperjalanannya,web-appspasarsambilegi. id telah mampu menghasilkan kebaruan nilai sosial dalam merubah perilaku berbelanja sebagian masyarakat. Konsumen yang berbelanja tersebut mengetahui penggunaan platform ini setelah medapatkan paparan promosi dari tim pengabdian UGM, Paguyuban Pasar Sambilegi dan Disperindag. Selain itu, model bisnis yang dikembangkan juga telah mampu menghasilkan keuntungan finansial. Pada pelaksanaan sebuah program, kedua hal tersebut dapat dikategorikan sebagai pencapaian outcome awal. Namun sayangnya, pengguna yang memanfaatkan sistem daring ini masih sangat tergantung dengan kegiatan promosi. Keuntungan finansial yang didapatkan juga masih terbatas, hanya untuk menutup biaya operasionalnya dan belum dapat meghasilkan penguatan kas kelompok seperti yang diharapkan.

Dalam kesepakatan bersama di awal perencanaan, sejatinya kas kelompok ini akan digunakan untuk membiayai pengembangan program dan juga untuk untuk menjalankan kegiatan - kegiatan lain dalam menanggulangi permasalahan COVID-19 yang terjadi di Pasar Sambilegi. Harapan utamanyaakan dapat mencapai perubahan sosial yang sistemik (impact), berupa peningkatan volume berbelanja dan penurunan penyebaran COVID-19 di wilayah layanan.

\section{Diskusi}

Seperti disampaikan oleh Murray dkk. (2010) bahwa proses pengembangan inovasi sosial antara satu dan lainnya tidak akan memiliki tahapan yang sama, dan bahkan tahapan tersebut bisa saling tumpang tindih atau beririsan. Hal ini juga terjadi pada proses pengembangan web-apps pasarsambilegi.id sebagai inovasi sosial berbasis digital. Proses menghasilkan gagasan bersama, misalnya, tidak hanya berjalan pada diskusi awal namun berlangsung sepanjang proses inovasi, baik pada tahapan perencanaan maupun implementasi program. Paguyuban bersama mitra dalam hal ini, senantiasa berdiskusi untuk mencari solusi permasalahan terkait operasionalisasi dan pengembangan pasarsambilegi.id.

Inovasi sosial pasarsambilegi.id bukan hanya tentang munculnya sebuah produk inovasi digital yang dapat memenuhi kepentingan pedagang pasar tradisional berdagang dengan pembeli, namun juga suatu bentuk pembuktian pentingnya kekuatan kolektif dalam sebuah komunitas. Seperti pernyataan Yue dkk (2015) bahwa kemampuan kolektif komunitas menjadi salah satu pendukung utama dalam proses inovasi digital yang didalamnya terdapat proses pemberdayaan melalui tahapan power shifting dan power reforming. Dalam hal power shifting, recognition yang merupakan pemetaan pengetahuan dan penggunaan teknologi oleh masyarakat pedagang Pasar Sambilegi terlihat bervariasi, dengan ketimpangan pengetahuan yang cukup tinggi. Sedangkan pada tahapan preparation, para pedagang yang bersedia terlibat dalam proses pengembangan, berperan dalam memberikan kemampuan serta pengetahuannya untuk menjalankan model bisnis belanja daring ini.

Sementara pada power reforming yang lebih membutuhkan pelibatan kolaborasi eksternal, terdapat tahapan recombination yang mengupayakan para pedagang (paguyuban), untuk mampu menjalankan sendiri model bisnis daring tanpa bergantung lagi kepada pendamping. Pada akhirnya pengembangan inovasi web-apps pasarsambilegi.id tidak hanya tentang penciptaaan sebuah platform namun juga proses transfer pengetahuan untuk meyakinkan bahwa ada beberapa alternatif bagi pedagang tradisional untuk bertahan di situasi krisis pandemi dengan berjualan secara daring. Selama berjalannya proses tersebut, tercipta ruang komunikasi intens antar pedagang dalam menjalankan pasar digital. Ruang tersebut menjadi tempat arus informasi pengetahuan di dalam komunitas. Tidak hanya tentang teknologi dan internet namun juga pengetahuan menjalankan kehidupan baru sebagai pedagang 
Matahari Farransahat, Acniah Damayanti, Hempri Suyatna, Puthut Indroyono, Rindu Sanubari Mashita Firdaus Pengembangan Inovasi Sosial Digital: Studi Kasus Pasarsambilegi.id

di tengah pandemi, pengetahuan menjalankan fungsi pemasaran untuk mempromosikan kepada para pelanggan untuk mencoba pasarsambilegi.id, serta pengetahuan untuk mengelola kemitraan dengan pihak-pihak yang dapat saling membantu untuk menghadapi masa krisis seperti pihak pemerintah, akademisi, relawan, dan sebagainya.

Aspek kepemimpinan memegang peranan penting dalam proses adopsi inovasi pasarsambilegi.id oleh paguyuban Pedagang Pasar Sambilegi. Ketua paguyuban yang juga berperan sebagai opinion leader melihat bahwa inovasi ini mempunyai manfaat relatif bagi proses bisnis Pasar Sambilegi dan mempunyai kemauan untuk mempelajari sistem jual beli baru sehingga inovasi relatif mudah untuk diimplementasikan. Selain itu, Ketua Paguyuban dan beberapa pedagang telah memiliki pengetahuan mengenai teknologi informasi dan pengalaman dalam jual beli daring. Pengelolaan pengetahuan kolektif ini selanjutnya menjadi sumber daya pendukung bagi berjalannya proses inovasi.

Platform pasarsambilegi.id sebagai entitas kewirausahaan sosial mengusung nilai baru dalam proses bisnis pasar tradisional dan berupaya untuk menyelesaikan persoalan sosial yang sedang terjadi di masyarakat. Pun begitu dari sisi profitability, pasarsambilegi.id belum dapat berfungsi secara optimal. Aspek kreativitas dalam model Okpara dan Halkias (Okpara \& Halkias, 2011) nampaknya bukan hanya berperan dalam tahap perencanaan atau desain inovasi namun juga pada tahap pemasaran ide inovasi kepada masyarakat. Nilai-nilai baru yang tercipta dalam proses inovasi sosial bisa jadi merupakan nilai atau ide yang tidak familiar bagi komunitas internal dan eksternal, atau dalam konteks ini pedagang Pasar Sambilegi dan pembeli, sehingga kreativitas sangat dibutuhkan dalam sosialiasi dan pengembangan platform demi menjaga keberlanjutan inovasi.

Potensi replikasi yang akan diterapkan pada pasar tradisional lainnya mensyaratkan pasarsembilegi.id untuk terus berkembang. Pada saat ini, kondisi web-apps belanja daring tersebut berada pada masa yang krusial, akankah gagal atau terus berhasil berkembang. Seperti disampaikan oleh Mulgan (2006), agar inovasi sosial tidak gagal, penting untuk meningkatkan mekanisme promosi yang efektif, meningkatkan jumlah penggunanya, dan mendapatkan dukungan dari berbagai pemangku kebijakan. Selain itu, juga penting untuk memperkut komponen-komponen penyusun kewirausahaan sosial yang ada pada sebuah inovasi sosial (Okpara \& Halkias, 2011), diantaranya adalah inovasi dan kreatifitas, kepemimpinan, pemanfaatan peluang, kemampuan menghasilkan keuntungan, penciptaan nilai, dan manfaat sosial bagi masyarakat.

Pengembangan inovasi sosial di pasar sambilegi ini tentunya mengalami tantangan dalam pelaksanaannya. Seperti kapasitas masyarakat dalam mengakses platform ini. Sebagian besar pedagang belum melek digital sehingga perlu pendekatan yang lebih intens untuk edukasi melek digital ini. Oleh karena edukasi dan pemberian pengetahuan untuk melek digital ini perlu terus dilakukan kepada pedagang khususnya pengurus paguyuban yang menjadi aktor utama dalam pengembangan pasar sambilegi.id. Keberadaan tokoh dalam paguyuban memang penting untuk pengembangan pasar ini, namun adanya tokoh yang terlalu dominan juga tidak baik karena akan menghambat proses demokratisasi dalam pengelolaan pasar.

\section{Kesimpulan}

Proses pengembangan pasarsambilegi. $i d$, sebagai inovasi sosial dalam upaya penanggulangan COVID-19, memiliki komponen penyusun yang sama dengan program kewirausahaan sosial. Inovasi sosial ini telah mampu mencapai outcome awal, yaitu penciptaan nilai sosial baru yang berupa pemanfaatan sistem belanja daring bagi sebagian masyarakat, dan hasil pendapatan untuk menutup kegiatan operasional. Namun, untuk bisa mencapai perubahan sistemik yang diharapkan, masih membutuhkan waktu lebih lama, khususnya dalam meningkatkan jumlah pengguna. Maka, agar dapat direplikasikan kepada pasar tradisional lainnya, kegiatan promosi pemanfaatan web-apps pasarsambilegi. id perlu digiatkan. Kegiatan ini tidak hanya berupa sosialisasi penggunaan, melainkan juga riset pasar untuk mengetahui segmen pengguna yang paling potensial. Dengan begitu, peningkatkan jumlah pengguna akan dapat meningkatkan volume perdagangan dan mengefisienkan operasional usaha, sehingga dapat menghasilkan keuntungan yang lebih besar. 


\section{Referensi}

Accenture. (2020). How China is Using Digital Digital and and to Technologies to Combat COVID-19. April, 8. https://www. accenture.com/_acnmedia/PDF-121/ Accenture-How-China-is-Using-Digitaland-Technologies-to-Combat-COVID-19. pdf diakses pada 25 Juli 2020.

Anania, L., \& Passani, A. (2014). A Hitchiker 's Guide to Digital Social Innovation. 20th Biennial Conference of the International Telecommunications Society (ITS): "The Net and the Internet - Emerging Markets and Policies," 1-11.

Bencana, B. N.P. (2020). Infografis Data.https:// loker.bnpb.go.id/s/G4jBmNCqTsCLyp8 diakses pada 31 Juli 2020.

Bria, F., Almirall, E., Baeck, P., Halpin, H., Kingsbury, J., \& Kresin, F. (2014). Digital social innovation: Interim report.

Cangiano, S., Romano, Z., \& Loglio, M. (2017). The growth of digital social innovation in Europe. for the societal good The growth of digital social innovation in Europe. An Open Design approach to support innovation for the societal good. The Design Journal, 6925, S3546-S3559. https://doi.org/10.1080/1 4606925.2017.1352857.

Caulier-Grice, J., Davies, A., Patrick, R., \& Norman, W. (2012). Defining Social Innovation. Proyecto TEPSIE, May, 43. http://youngfoundation.org/wp-content/ uploads/2012/12/TEPSIE.D1.1.Report. DefiningSocialInnovation.Part-1-definingsocial-innovation.pdf.

Cui, M., Pan, S. L., Newell, S., \& Cui, L. (2017). Strategy, resource orchestration and e-commerce enabled social innovation in Rural China. The Journal of Strategic Information Systems, 26(1), 3-21.

Curtis, T. (2010). The challenges and risks of innovation in social entrepreneurship. In R. Gunn \& C. Durkin (Eds.), Social Entrepreneurship: A skills approach (pp. 83-98). Policy Press.

Dhewanto, W., Mulyaningsih, H., \& Permatasari, A. (2013). Inovasi dan Kewirausahaan Sosial (Kesatu). Alfabeta.

Insider, B. (2020). As China lifts its coronavirus lockdowns, authorities are using a colorcoded health system to dictate where citizens can go. Here's how it works diakses pada 28 Juli 2020.
Kompas. (2020). Jadi Salah Satu Klaster Penularan COVID-19, Ini Cara Agar Aman Belanja di Pasar Tradisional. https: / / nasional.kompas.com / $\mathrm{read} / 2020 / 06 / 14 / 09103461 /$ jadi-salahsatu-klaster-penularan-COVID-19-inicara-agar - aman-belanja-di page $=$ all diakses pada 27 Juli 2020.

Manzini, E. (2014). Making things happen: Social innovation and design. Design Issues, 30(1), 57-66. https://doi.org/10.1162/ DESI.

Menteri Perdagangan. (2020). Pemulihan aktivitas perdagagan yang dilakukan pada masa pandemic corona virus disease 2019 (COVID-19) dan new normal. https:// covid19.hukumonline.com/wp-content/ uploads/2020/05/surat_edaran_menteri_ perdagangan_nomor_12_tahun_2020.pdf diakses pada 27 Juli 2020.

Menteri Perdagangan. (2020). Pemulihan aktivitas perdagagan yang dilakukan pada masa pandemic corona virus disease 2019 (COVID-19) dan new normal. https:// covid19.hukumonline.com/wp-content/ uploads/2020/05/surat_edaran_menteri_ perdagangan_nomor_12_tahun_2020.pdf diakses pada 27 Juli 2020.

Mulgan, G. (2006). The process of social innovation. Innovations: Technology, Governance, Globalization, 1(2), 145-162.

Murray, R., Caulier-Grice, J., \& Mulgan, G. (2010). The open book of social innovation. National Endowment for Science, Technology and the Art. https://doi.org/10.1371/journal. pcbi.0030166.

Okpara, J. 0., \& Halkias, D. (2011). Social entrepreneurship: an overview of its theoretical evolution and proposed research model. International Journal of Social Entrepreneurship and Innovation, 1(1), 4. https://doi.org/10.1504/ ijsei.2011.039808.

Phills, J. A., Deiglmeier, K., \& Miller, D. T. (2008). Rediscovering social innovation. Stanford Social Innovation Review, 6(4), 34-43.

Tanimoto, K. (2012). The emergent process of social innovation: multi-stakeholders perspective. International Journal of Innovation and Regional Development, 4(3/4), 267. https://doi.org/10.1504/ ijird.2012.047561. 
Matahari Farransahat, Acniah Damayanti, Hempri Suyatna, Puthut Indroyono, Rindu Sanubari Mashita Firdaus -

Pengembangan Inovasi Sosial Digital: Studi Kasus Pasarsambilegi.id

Tracey, P., \& Stott, N. (2017). Social innovation: a window on alternative ways of organizing and innovating. Innovation: Management, Policy and Practice, 19(1), 51-60. https:// doi.org/10.1080/14479338.2016.1268924.

West, D. M. (2013). The next wave: Using digital technology to further social and political innovation. Brookings Institution Press.
Yue, L., Pan, S. L., Tan, B., \& Cui, L. (2015). Digitally enabled social innovation: A case study of community empowerment in rural China. Thirty Sixth International Conference on Information Systems, 1-11. 